\title{
An assessment of fruiting and polyembryony in Langsat (Lansium domesticum Corr.) from Nilgiris, India
}

\author{
Kanupriya*, Pushpa Chethan Kumar and Anuradha Sane \\ ICAR-Indian Institute of Horticultural Research \\ Hessaraghatta Lake Post, Bengaluru - 560 089, India \\ *E-mail: Kanupriya@ icar.gov.in
}

\begin{abstract}
In this paper we report the fruit characteristics and seed polyembryony in langsat, Lansium parasiticum (syn. Lansium domesticum Corr.). This fruit tree belongs to the family Meliaceae in order Sapindales and is considered to be native of western South East Asia and is common in both wild and cultivated forms throughout Malaysia and Philippines where the fruits are very popular and the tree is being utilized in reforestation efforts. It is also grown in southern Thailand and Vietnam and flourishes in the Nilgiris and other humid areas of South India. In the present investigation we report the morphological and biochemical parameters of the plants and fruits obtained from State Horticultural Farm, Buliar (latitude 11.34; longitude 76.79) in Tamil Nadu, at elevation of $360 \mathrm{~m}$ MSL and receiving average annual rainfall of $125.14 \mathrm{~cm}$. The plantation was established in the year 1900 and consists of various tropical trees like mangosteen, langsat, arecanut, coffee, silveroak, pepper, cinnamon in tier system of planting.
\end{abstract}

Key words: Langsat, polyembryony, Nilgiris

\section{INTRODUCTION}

The langsat is an erect, slender or spreading type of tree; reaching $12-15 \mathrm{~m}$ in height, with red-brown furrowed bark. Its leaves are pinnate, $22-50 \mathrm{~cm}$ long, with 5 to 7 alternate leaflets, elliptic - oblong, pointed at both ends, dark-green and glossy on upper surface, paler and dull beneath with a prominent midrib. The flowers are mostly bisexual, small, pale-yellow borne in branched racemes on the trunk and oldest branches, at first they are erect and finally pendant, 10 to $30 \mathrm{~cm}$ in length (Morton, 1987). The fruit is borne in cluster of 2 to 30 (Fig A), it is oval, ovoidoblong or nearly round, 2.5 to $5 \mathrm{~cm}$ in diameter, weighing $200 \mathrm{~g}$ on an average with the contribution of seed approximately 7 percent of the weight. The fruits are non-climactric in nature like pomegranates and citrus and have to be allowed to fully mature on the tree to obtain optimum taste. The peel of the fruit is pale brown, thin, velvety and contains milky latex. There are 3 or 5 segments of aromatic, white, translucent, juicy flesh called arils with sweet- sour taste, bit similar to litchi (Fig B). The seeds adhere to the flesh and are present in 1 to 3 of the aril segments. They are green, relatively large- 2 to 2.5 $\mathrm{cm}$ long and 1.25 to $2 \mathrm{~m}$ wide and bitter tasting. The peel of the fruit is considered to be high in tannins and the arils are high in total phenol content. The TSS of the fleshy arils varies from 14 to $17^{\circ}$ Brix depending on the maturation of the fruit, the titratable acidity (as percent citric acid) decreases as the fruit matures from 2 to $0.5 \%$ and the ascorbic acid content of the fruit is around $1 \mathrm{mg} / 100 \mathrm{~g}$. The fruits are known to suffer from aril browning due to the activity of polyphenol oxidase, which significantly reduces the marketability of the fruits (Huang et al 2010). The seed has been reported to contain a minute amount of an unnamed alkaloid, $1 \%$ of an alcohol- soluble resin, and two bitter, toxic principles (Venkatachalam and Meenune 2012). An arrow poison has been made from the fruit peel and bark of the tree. Both are known to possess a toxic property, lansium acid, which is known to arrest heartbeat in frogs. The dried peel is burned in Java to serve as mosquito repellent and the wood is utilized for house posts, rafters, tool handles and small utensils. The pulverized seed is 


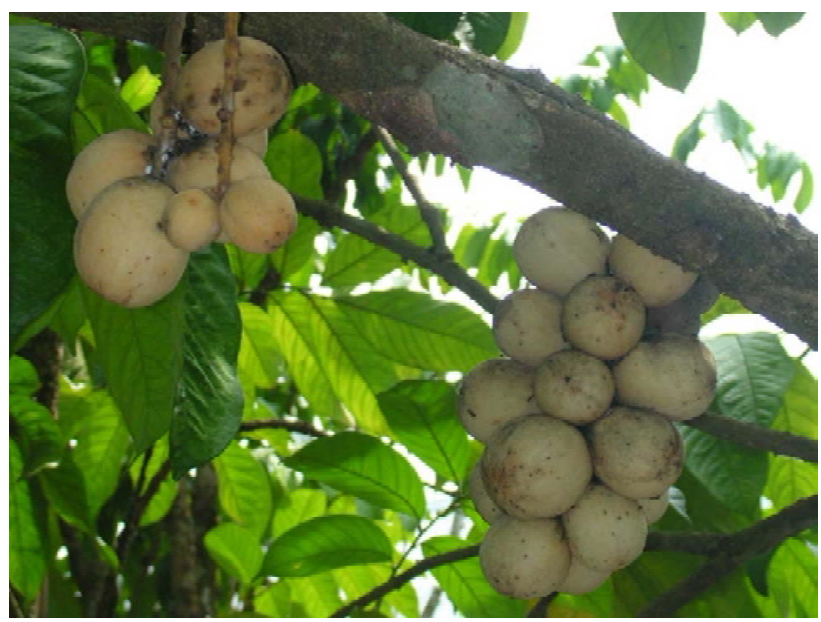

Fig. A: Langsat fruit borne in clusters on tree

employed as febrifuge and vermifuge. The bark paste is used as poultice on scorpion stings. An astringent bark decoction is used as treatment for dysentery and malaria. Leaf juice is used as eye-drops to dispel inflammation (Samuagam et al.,2015).

Polyembryony is the phenomenon of occurrence of more than one embryo in a seed leading to emergence of several seedlings from a seed. In true polyembryony, additional embryos arise by several ways such as splitting of zygote or proembryo called cleavage polyembryony which is more common in gymnosperms, from cells of embryo sac other than the egg (apogamy) or nucellar or integumentary cells outside the embryo sac (adventive embryony) (Maheshwari 1952). Depending on the origin, the embryos can be genetically different (Ganeshaiah et al 1991). Little is known about the outcome of polyembryony, which seems to increase the fitness of the mother plant by increasing the chances of establishment of at least one of the seedlings from the same seed (bet hedging). Polyembryony can also be beneficial, as more seedlings are produced by the same investment of the mother plant (Shaankeer and Ganeshaiah, 1997). On the other hand, competition may arise during germination for the food reserves (e.g., cotyledons, endosperm), between embryos which may reduce vigour. In Meliaceae, polyembryony appears to be an unusual phenomenon and has been described only for a few genera. On the other hand, polyembryony is reported in several fruit crops of tropical regions (Table 1). In langsat it is a common phenomenon with more than $50 \%$ of seeds giving more than one seedling. Fresh seeds take about 10 days to germinate and the first leaf is formed by

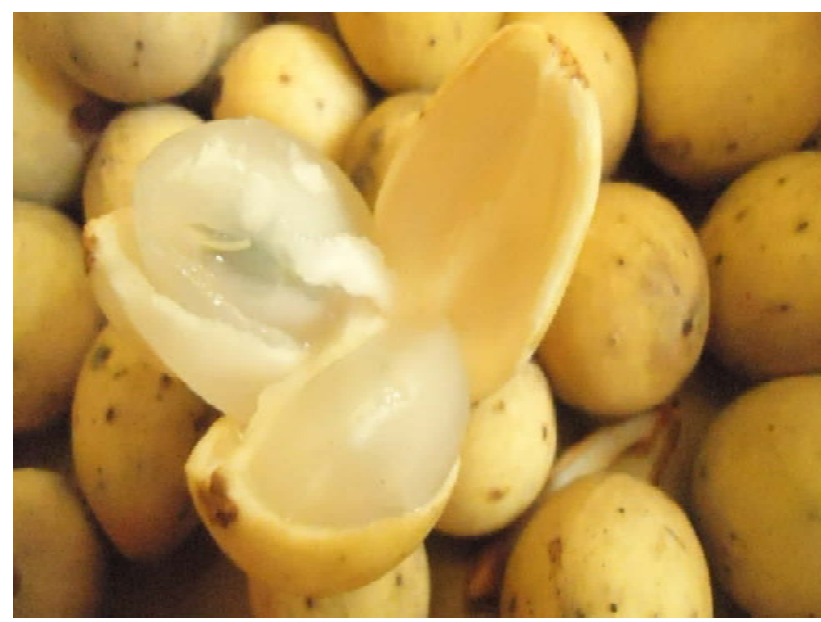

Fig. B: Individual fruit opened to show the fleshy arils

the fourth week. Germination is hypogeal. In a seed with more than one embryo, a number of shoots are formed each having its own root system and may be separated out as separate seedlings. Where there is only one embryo, only one seedling is formed. However, in certain cases there are multiple shoots, with only one root system. In such cases only one shoot is vigorous and the others die off in time (Salma and Razali 1957)

In this study, langsat fruits were obtained from State Horticultural Farm, Buliar (latitude 11.34; longitude 76.79) in Tamil Nadu, at elevation of $360 \mathrm{~m} \mathrm{MSL}$ and receiving average annual rainfall of $125.14 \mathrm{~cm}$. The plantation was established in the year 1900 and consists of various tropical trees like mangosteen, langsat, arecanut, coffee, silver oak, pepper, cinnamon in tier system of planting. Ten fruits were collected and analyzed for physico-chemical parameters as per the methods described by Ranganna (1986) in triplicates. The seed weight ranged from 1.56 to $0.77 \mathrm{~g}$, pulp weight from 13.5 to $6.69 \mathrm{~g}$ and peel weight from 5.1 to $2.53 \mathrm{~g}$, accounting to $7.76,66.94$ and $25.3 \%$ of total weight of the fruit, respectively. The pulp was analyzed for biochemical parameters such as TSS which was found to be $13.73{ }^{\circ}$ Brix, titratable acidity (as \% citric acid) was $2.34 \%$ and ascorbic acid was $8.53 \mathrm{mg} / 100 \mathrm{~g}$ (Table 2). Sensory evaluation revealed that fruit color was pale brown, pulp color was whitish jelly type similar to litchi pulp, the taste was sweet with bit sour similar to taste of litchi fruit (Table 3).

The seeds were used to determine various parameters such as percent germination, viability, 
number of seedlings obtained per seed (polyembryony) were recorded for ten seeds by germinating them in wet towel. Hundred percent germination was observed with the number of embryo per seed ranging from 2 to 5 . Four seeds $(40 \%)$ gave rise to two plants, four seeds $(40 \%)$

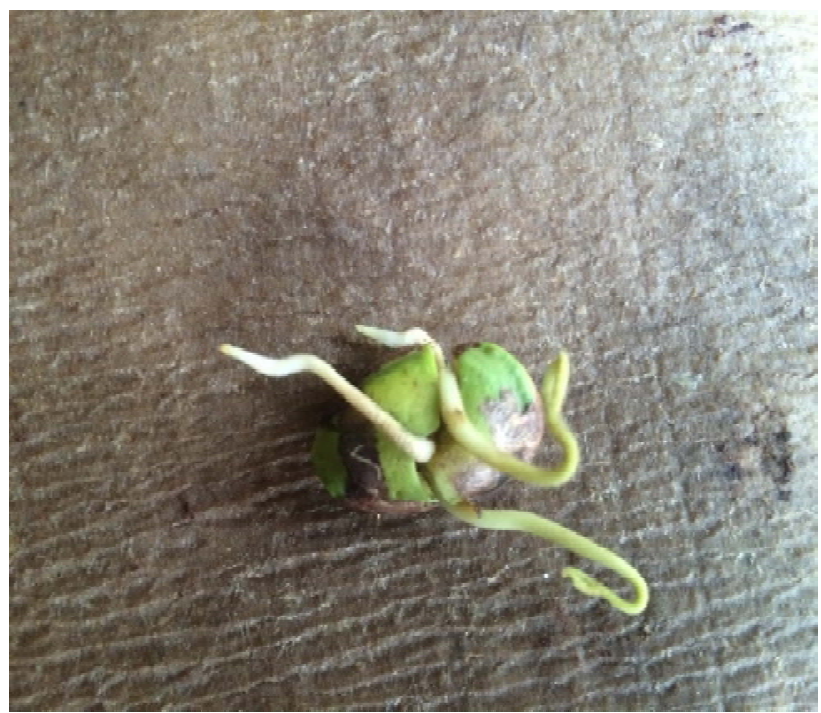

Fig. C: Germinating polyembryonic seed with four seedlings

In today's world, where consumers are looking for novel fruits and varieties langsat can prove to be a good species for the areas experiencing tropical climate. It has been reported that despite the various types that have been identified, the genetic variability is still too narrow for meaningful breeding efforts in this crop (Salma and Razali 1957). It also suffers from long juvenility period gave rise to three plants while four and five plants were obtained from one seed (10\%) each (Fig C). The seedlings were planted in polybags containing soil: sand: FYM mixture in 2:2:1 ratio (Fig D). Good establishment was observed and the plants were transferred to field for further evaluation.

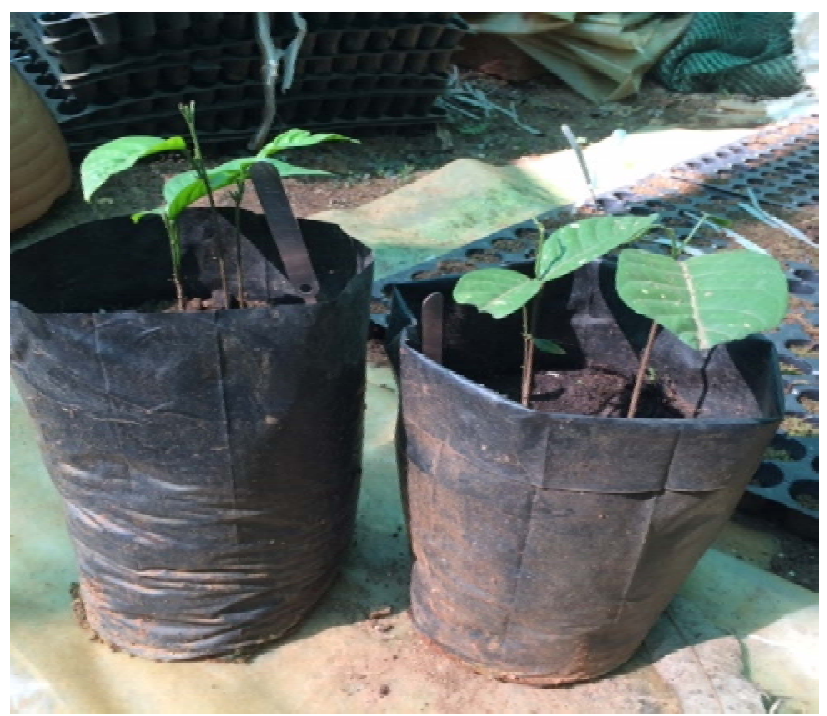

Fig. D: The potted seed giving rise to three and two seedlings each

and the fruits are pathenocarpically developed making hybridization ineffective. The fruits are often not uniform in size, the tree is prone to bark borers, and the tree architecture needs a lot of pruning for better fruit formation and facilitate easier harvesting. A lot of breeding efforts is needed to improve the genetic characteristics of this species before it can really have an industrial impact.

Table 1: Polyembryony reported in different families of tropical fruits

\begin{tabular}{lll}
\hline Families & Scientific name & Common name \\
\hline Anacardiaceae & Mangifera indica & Mango \\
Guttiferae & Garcinia mangostana & Mangosteen \\
Meliaceae & Lansium domesticum & Langsat \\
Myrtaceae & Eugenia spp, Myrciaria cauliflora & Rose apple/ Malay apple, Jaboticaba \\
Rutaceae & Citrus spp & Orange \\
\hline
\end{tabular}


Table 2: Physico-chemical parameters of langsat fruit on fresh weight basis

\begin{tabular}{llll}
\hline Parameter & Mean & SD & SE \\
\hline TSS $\left({ }^{\circ}\right.$ Brix) & 13.73 & 0.11 & 0.06 \\
Titratable acidity $(\%)$ & 2.34 & 0.03 & 0.02 \\
Ascorbic acid $(\mathrm{mg} / 100 \mathrm{~g})$ & 8.53 & 0.92 & 0.53 \\
Fruit length $(\mathrm{mm})$ & 31.537 & 2.55 & 0.81 \\
Fruit breadth $(\mathrm{mm})$ & 23.383 & 1.96 & 0.62 \\
Fruit weight $(\mathrm{g})$ & 13.42 & 0.16 & 0.05 \\
Pulp weight $(\mathrm{g})$ & 10.92 & 2.36 & 0.75 \\
Seed weight $(\mathrm{g})$ & 1.24 & 0.4 & 0.13 \\
Peel weight $(\mathrm{g})$ & 3.55 & 0.95 & 0.3 \\
\hline
\end{tabular}

Table 3: Appearance and sensory evaluation of fresh langsat fruit

\begin{tabular}{ll}
\hline Sensory parameter & Observation \\
\hline Fruit color & Pale brown \\
Pulp color & Whitish jelly type \\
Taste & Sour \\
Aroma & Bland \\
Flavour & Bland \\
\hline
\end{tabular}

\section{REFERENCES}

Morton, J. Langsat. In: Fruits of warm climates. Julia F. Morton, Miami, Florida, 1987, p.201-201

Huang, W.Y., Cai, Y.Z., Corke, H. and Sun, M.2010. Survey of antioxidant capacity and nutritional quality of selected edible and medicinal fruit plants in Hong Kong. J Food Compo Analysis, 23(6):510-517.

Ranganna, S. 1986. Handbook of Analysis and Quality Control for Fruit and Vegetable Products. Tata McGraw Hill Pub. Co. Ltd., New Delhi.

Samuagam, L., Sia, C.M., Akowuah, G.A., Okechukwu, P.N. and Yim, H.S.2015. In vivo antioxidant potentials of rambutan, mangosteen, and langsat peel extracts and effects on liver enzymes in experimental rats Food Sci Biotechnol.,24(1):191-198

Venkatachalam, K. and Meenune, M.2012. Changes in physiochemical quality and browning related enzyme activity of longkong fruit during four different weeks of on-tree maturation. Food Chemistry, 131(4):14371442

Maheshwari, P. 1952. Polyembryony in Angiosperms, Palaeobotanist, 1: 319-329.

Salma, I and Razali, B. 1957. The reproductive biology of langsat in Peninsular Malaysia

Mardi Res. Bull., 15(2) :141-150

Ganeshaiah, K.N., Shaanker R.U., Joshi N.V. 1991. Evolution of polyembryony: consequences to the fitness of mother and offspring. J Genetics 70: 103-127

Shaankeer R.U, Ganeshaiah K.N. 1997. Conflict between parent and offspring in plants: predictions, processes and evolutionary consequences Current Sci., 72: 932-939

(MS Received 05 October 2018, Revised 21 February 2019, Accepted 07 May 2019) 